\title{
The last giant Araucaria trees in southern Brazil
}

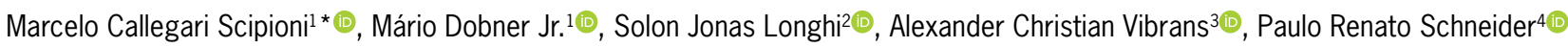

\begin{abstract}
IUniversidade Federal de Santa Catarina - Depto. de Agricultura, Biodiversidade e Florestas, Rod. Ulysses Gaboardi, km 3 - 89520-000 - Curtibanos, SC - Brasil. 2Universidade Tecnológica Federal do Paraná, Est. para Boa Esperança, km 04 - 85660-000 - Dois Vizinhos, PR - Brasil. ${ }^{3}$ Universidade Regional de Blumenau - Depto. de Engenharia Florestal, R. São Paulo, 3250 - 89030-000 - Blumenau, SC - Brasil. ${ }^{4}$ Universidade Federal de Santa Maria - Depto. de Ciências Florestais, Av. Roraima, 1000 - 97105-900 - Santa Maria, RS - Brasil.

${ }^{*}$ Corresponding author <marcelo.scipioni@gmail.com>
\end{abstract}

Edited by: Paulo Cesar Sentelhas

Received July 24, 2017

Accepted December 19, 2017
ABSTRACT: Araucaria angustifolia (Bertol.) Kuntze is a native tree species of major importance in southern Brazil. It is a regional symbol due to its iconic shape and stature in the landscape; its wood was once economically important and its seeds are an important source of food for the fauna and are presently used in regional cuisine. Despite its importance and apparent abundance, the species is facing extinction mainly as a result of unregulated exploitation and deforestation. This study catalogued the remaining individuals in order to add to the body of knowledge available on $A$. angustifolia, a species that has become rare across its historic range. The circumference at breast height $(1.30 \mathrm{~m})$, the total height, and the tree volume were measured (3,529 araucarias). We catalogued trees with a large diameter measuring them in loco over three years involving a journey of more than $6,800 \mathrm{~km}$. The volumes of these old trees are very large, ranging from $38.2 \mathrm{~m}^{3}$ to $106.6 \mathrm{~m}^{3}$. The largest $A$. angustifolia individual is located in the state of Santa Catarina and measures $3.25 \mathrm{~m}$ in diameter. The giant araucarias with $>2.00 \mathrm{~m}$ in diameter are rare and only 13 individuals could be found in southern Brazil; a priority action at the governmental level is to recognize and preserve these monumental trees and together with a need for a public policy of drawing up specific inventories of large trees.

Keywords: giant tree, large old tree, monumental trees, cavities trees, araucaria forest

\section{Introduction}

Giant trees are the largest and oldest (500 - 8000 years) living organisms on the earth's surface. Giant sequoias (Sequoiadendron giganteum) are the world's largest trees, with breast height diameters of up to $8.8 \mathrm{~m}$ (29 feet) and total height up to $93.5 \mathrm{~m}$ (307 feet). The presence of giant trees enhances terrestrial ecosystems as the large canopies increase biodiversity and biomass parameters (Franklin et al., 2002; Lindenmayer et al., 2012; Sillett, 1999; Sillett et al., 2015; Sillett and Van Pelt, 2000; Van Pelt, 2001). These trees are uniquely important as an in situ genetic resource (Stefenon et al., 2009) and as a source of habitats for fauna and flora (Lindenmayer and Laurance, 2016).

Giant trees are to be found all over the globe - except in the Antarctic continent -and are continually objects of interest to researchers who seek to record them for conservation programs and ecological studies (Tng et al., 2012; Van Pelt, 2001).

Araucaria angustifolia (Bertol.) Kuntze - Araucariaceae, (Brazilian pine or Paraná pine) is the characteristic species of the Araucaria Forest, in which they dominate the canopy or even widely surpass the canopy as emergent trees, and mature trees are among the largest trees in Brazil (Oliveira et al., 2009). The species is critically endangered (Thomas, 2013) and little is known about the existence and condition of giant trees (Mattos, 2011).

This species occurs in the southern and southeastern plateau of Brazil, in the northwest of Argentina, and in the southeast of Paraguay between 400 and $1800 \mathrm{~m}$ above sea level. Mature individuals are between 20 and $50 \mathrm{~m}$ in height with a single, erect, and cylindrical trunk measuring between 0.5 to $2.4 \mathrm{~m}$ in diameter. At least two thirds of the tree's crown lacks lateral branches, which makes the crown of the tree chalice-shaped (Albiero Jr. et al., 2015; Eckenwalder, 2009; Farjon and Filer, 2013; Oliveira et al., 2009; Reitz, 1966).

The aim of the present study was to catalogue the last largest Araucaria angustifolia of individuals, and record their dendrometric characteristics and locations across the whole natural distribution area in southern Brazil. Thereafter, the data collected were compared with the state inventories of Santa Catarina and Rio Grande do Sul to detect rarity and size classes of big araucaria trees.

\section{Materials and Methods}

\section{Study area}

Araucaria forests are concentrated in the southern region of Brazil (Figure 1). Our research was conducted over a three year period; we selected trees for our study using published bibliographies (Mattos, 2011) and reports, an online platform (www.arvoresgigantes. org), and recommendations from third parties in our personal networks. More than 6,813 km (4.233 miles) were travelled on main and secondary roads in southern Brazil to visit rural properties and the different types of conservation units to verify and measure large trees. We visited seventeen rural properties and twelve different types of conservation units: Private Nature Heritage Reserve - RPPN (2), Indigenous Reserve (1), National Forests (3), and Municipal (2), State (1) and National (4) Parks. On-site measurements were taken from Feb 2015 to Mar 2017. The location of the giant trees measured in this study is given in Table 1 .

Data from the state forest inventories of Rio Grande do Sul and Santa Catarina were consulted to check the existence of large trees of $A$. angustifolia and to 
Table 1 - Location of the giant araucaria trees found in southern Brazil ranked by DBH.

\begin{tabular}{|c|c|c|c|c|}
\hline Ranking & Tree Name & Latitude & Longitude & Altitude (m) \\
\hline 1 & Pinheirão & $28^{\circ} 9^{\prime} 29.87^{\prime \prime} \mathrm{S}$ & $49^{\circ} 47^{\prime} 50.46^{\prime \prime} \mathrm{W}$ & 1345 \\
\hline 2 & Pinheiro Grosso & $29^{\circ} 21^{\prime} 4.75^{\prime \prime} \mathrm{S}$ & $50^{\circ} 50^{\prime} 2.52^{\prime \prime} \mathrm{W}$ & 781 \\
\hline 3 & Estação Experimental Embrapa 1 & $26^{\circ} 51^{\prime} 51.15^{\prime \prime} \mathrm{S}$ & $50^{\circ} 56^{\prime} 31.40^{\prime \prime} \mathrm{W}$ & 1050 \\
\hline 4 & Menina da Cústodia & $28^{\circ} 22^{\prime} 51.72^{\prime \prime} \mathrm{S}$ & $49^{\circ} 59^{\prime} 22.08^{\prime \prime} \mathrm{W}$ & 1240 \\
\hline 5 & Campos Novos & $27^{\circ} 16^{\prime} 58.60^{\prime \prime} \mathrm{S}$ & $51^{\circ} 10^{\prime} 42.90^{\prime \prime} \mathrm{W}$ & 989 \\
\hline 6 & Estação Experimental Embrapa 2 & $26^{\circ} 51^{\prime} 51.15^{\prime \prime} \mathrm{S}$ & $50^{\circ} 56^{\prime} 31.40^{\prime \prime} \mathrm{W}$ & 1050 \\
\hline 7 & Santo Anjo 1 & $27^{\circ} 50^{\prime} 54.40^{\prime \prime} \mathrm{S}$ & $49^{\circ} 17^{\prime} 52.50^{\prime \prime} \mathrm{W}$ & 1124 \\
\hline 8 & Araucária Gigante & $25^{\circ} 57^{\prime} 46.85^{\prime \prime} \mathrm{S}$ & $51^{\circ} 20^{\prime} 43.44^{\prime \prime} \mathrm{W}$ & 1035 \\
\hline 9 & Fazenda do Colégio & $28^{\circ} 18^{\prime} 48.40^{\prime \prime} \mathrm{S}$ & $49^{\circ} 57^{\prime} 4.21^{\prime \prime} \mathrm{W}$ & 1250 \\
\hline 10 & Pinheiro Multissecular & $29^{\circ} 21^{\prime} 6.69^{\prime \prime} \mathrm{S}$ & $51^{\circ} 3^{\prime} 7.06^{\prime \prime} \mathrm{W}$ & 731 \\
\hline 11 & Fazenda Santana & $25^{\circ} 1^{\prime} 14.85^{\prime \prime} \mathrm{S}$ & $49^{\circ} 56^{\prime} 25.80^{\prime \prime} \mathrm{W}$ & 986 \\
\hline 12 & Santo Anjo 2 & $27^{\circ} 50^{\prime} 48.20^{\prime \prime} \mathrm{S}$ & $49^{\circ} 17^{\prime} 39.90^{\prime \prime} \mathrm{W}$ & 1072 \\
\hline 13 & Gateados & $27^{\circ} 58^{\prime} 0.07^{\prime \prime} \mathrm{S}$ & $50^{\circ} 49^{\prime} 20.41^{\prime \prime} \mathrm{W}$ & 845 \\
\hline 14 & Estação Experimental Embrapa 3 & $26^{\circ} 51^{\prime} 51.15^{\prime \prime} \mathrm{S}$ & $50^{\circ} 56^{\prime} 31.40^{\prime \prime} \mathrm{W}$ & 1050 \\
\hline 15 & Fazenda Tupi & $28^{\circ} 42^{\prime} 23.02^{\prime \prime} \mathrm{S}$ & $51^{\circ} 36^{\prime} 46.01^{\prime \prime} \mathrm{W}$ & 700 \\
\hline 16 & São Cristovão do Sul & $27^{\circ} 20^{\prime} 20.00^{\prime \prime} \mathrm{S}$ & $50^{\circ} 22^{\prime} 32.68^{\prime \prime} \mathrm{W}$ & 1080 \\
\hline 17 & Pinnheiro do Mico & $26^{\circ} 47^{\prime} 48.39^{\prime \prime} \mathrm{S}$ & $50^{\circ} 0^{\prime} 19.84^{\prime \prime} \mathrm{W}$ & 627 \\
\hline 18 & Terra Indígena Mangueirinha & $25^{\circ} 55^{\prime} 42.96^{\prime \prime} \mathrm{S}$ & $52^{\circ} 22^{\prime} 3.54^{\prime \prime} \mathrm{W}$ & 828 \\
\hline 19 & Santo Anjo 3 & $27^{\circ} 50^{\prime} 55.60^{\prime \prime} \mathrm{S}$ & $49^{\circ} 17^{\prime} 47.10^{\prime \prime} \mathrm{W}$ & 1106 \\
\hline 20 & Floresta René Fray & $27^{\circ} 1 ' 2.98^{\prime \prime} \mathrm{S}$ & $50^{\circ} 55^{\prime} 36.42^{\prime \prime} \mathrm{W}$ & 1056 \\
\hline 21 & Brochmann Polis & $27^{\circ} 21^{\prime} 53.70^{\prime \prime} \mathrm{S}$ & $50^{\circ} 57^{\prime} 12.00^{\prime \prime} \mathrm{W}$ & 957 \\
\hline
\end{tabular}

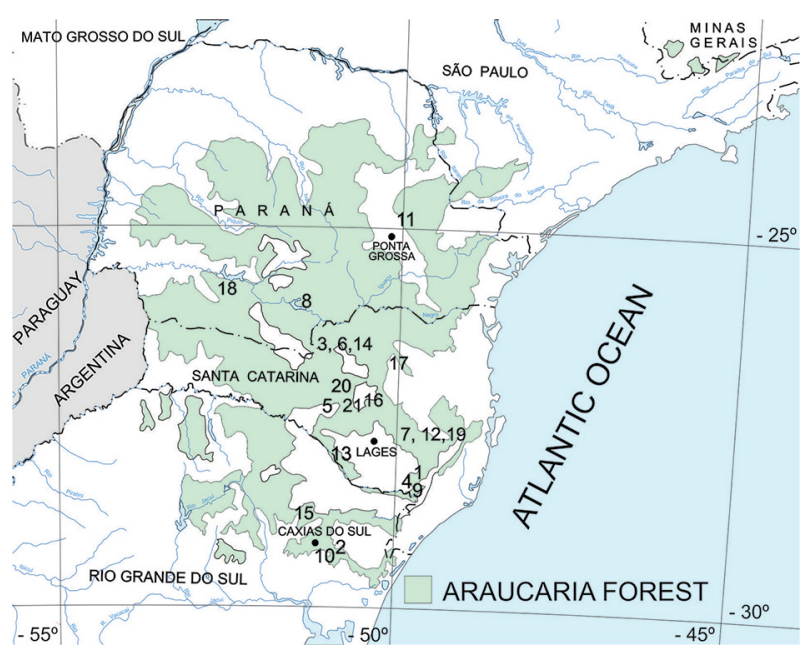

Figure 1 - Location of the giant Araucaria angustifolia trees in southern Brazil, categorized by diameter. Trees characterizations are given in Figure 2. Map adapted from IBGE (2012).

help in the search for places in a good state of conservation to research. A full description of sampling projects and protocols can be found in the IFCRS - Continuous Forest Inventory of Rio Grande do Sul (http://coralx. ufsm.br/ifcrs/) and IFFSC - Forest and Floristic Inventory of Santa Catarina sites (http://www.iff.sc.gov.br/). There is no state forest inventory for the state of Paraná. Several other publications were also consulted in the search for large trees (Albiero Jr. et al., 2015; Chassot et al., 2011; Farjon and Filer, 2013; Mattos et al., 2007; Narvaes et al., 2005; Scheeren et al., 2000; Stepka et al.,
2014). The diameter at breast height (DBH) and height of the giant araucarias were compared with all araucarias measured $(\mathrm{DBH}>10 \mathrm{~cm})$ as per the state inventories of Rio Grande do Sul and Santa Catarina, (3,529 araucaria trees).

\section{Dendrometry}

The initial selection criterion for giant araucaria was a diameter at breast height $(\mathrm{DBH}, 1.3 \mathrm{~m})$ of greater than or equal to $200 \mathrm{~cm}$. However, for definition of the giant araucaria class, trees with smaller diameters (< $200-150 \mathrm{~cm}$ ) are also ecologically important and the data of these trees were also evaluated using the data from state forest inventories. Individual histories of trees included in this study were obtained from the owners or managers of the areas where the trees are located. Only the city name and the name of the locale or property are provided herein, rather than a specific geographic location for each tree, since the visitation of most trees required prior authorization and scheduling.

The circumference at breast height $(1.30 \mathrm{~m})$, the total height, and the volume were measured following methodologies in Van Pelt (2001). Measuring tape and dendrometers were used. Tree volume was determined by measuring diameters at various heights with laser equipment (Criterion 400) installed on a levelled tripod. We also measured the height at which the secondary branches (reiteration trunks) intersected the main trunk. We calculated trunk volume using the Smalian method and included diameters of extremities in each section. The Huber method was used only for reiteration trunks; a single diameter reading was taken in the centre of the section. The total tree volume consisted of the sum of 
the main trunk volume and the reiteration trunk volumes. Araucaria angustifolia trees that had overlapping canopies were difficult to measure as trunks were visually obscured. The volumes of these trees were estimated by means of an average artificial form factor based on eight studied trees above two meters in diameter (Figure 2). The total height of these trees were measured using Trupulse $200 \mathrm{~B}$ positioned at ground level creating a $90^{\circ}$ angle, targeting the top of the highest branch. For trees with a damaged crown, measurement of the main trunk together with the height where the fallen secondary branches intersected the main trunk were used to estimate the total height.

The cavity areas at the base of the tree trunk were measured using metric tape and laser equipment. In cavities large enough for a person to stand in, basal area measurements of the cavity were calculated by measuring eight radii from the central axis of the tree. The

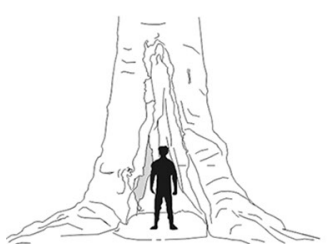

$1^{\text {st }}$ position Pinheirão São Joaquim - SC $\mathrm{DBH}=3.25 \mathrm{~m}$ $\mathrm{CBH}=10.23 \mathrm{~m}$ Height $=39.2 \mathrm{~m}$ $106.6 \mathrm{~m}^{3} / \mathrm{f}_{13}: 0.3279$

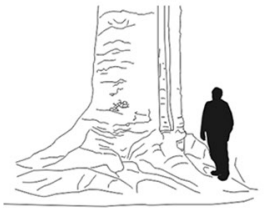

$5^{\text {th }}$ position

Campos Novos - SC $\begin{aligned} \mathrm{DBH} & =2.21 \mathrm{~m} \\ \mathrm{CBH} & =6.97 \mathrm{~m}\end{aligned}$ Height $=44 \mathrm{~m}$ $63.70 \mathrm{~m}^{3}$

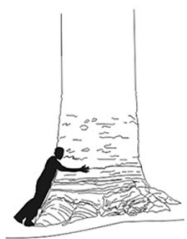

$10^{\text {th }}$ position

Pinheiro Multissecular
Nova Petrópolis - RS DBH $=2.07 \mathrm{~m}$ $\mathrm{CBH}=6.51 \mathrm{~m}$ Height $=\sim 35.1 \mathrm{~m}$ $44.3 \mathrm{~m}^{3} / \mathrm{f}_{1,3}: 0.3320$

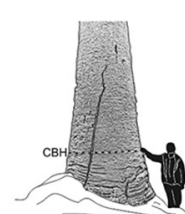

$16^{\text {th }}$ position

Faxinalzinho

São Cristovão do Sul -

$\mathrm{DBH}=1.91 \mathrm{~m}$

$\mathrm{CBH}=6.01 \mathrm{~m}$

Height $=\sim 35.0 \mathrm{~m}$ $\sim 38.2 \mathrm{~m}^{3}$

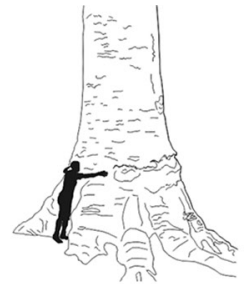

$2^{\text {nd }}$ position

Pinheiro Grosso Canela - RS $\mathrm{DBH}=2.68 \mathrm{~m}$ $\mathrm{CBH}=8.44 \mathrm{~m}$ Height $=39 \mathrm{~m}$
$72.1 \mathrm{~m}^{3} / \mathrm{f}_{13}: 0.3277$

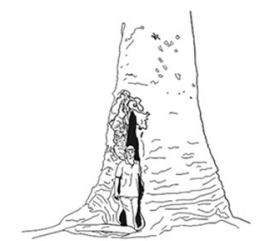

$3^{\text {rd }}$ position

Estação Experimental da Embrapa 1 Caçador - SC $\mathrm{DBH}=2.38 \mathrm{~m}$ $\mathrm{CBH}=7.48 \mathrm{~m}$ Height $=44 \mathrm{~m}$ $62.4 \mathrm{~m} / \mathrm{f}_{1,3}: 0.3279$

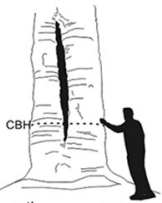

$6^{\text {th }}$ position Estação Experimental da Embrapa 2 Caçador - SC $\mathrm{DBH}=2.21 \mathrm{~m}$ $\mathrm{CBH}=6.97 \mathrm{~m}$ Height $=40 \mathrm{~m}$ $61.8 \mathrm{~m}^{3} / \mathrm{f}_{1,3}: 0.4585$

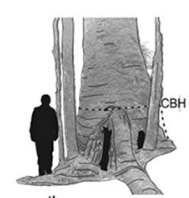

$7^{\text {th }}$ position Santo Anjo 1 Alfredo Wagner - SC $\mathrm{DBH}=2.20 \mathrm{~m}$ $\mathrm{CBH}=6.92 \mathrm{~m}$ Height $=37 \mathrm{~m}$ $52.5 \mathrm{~m}^{3}$

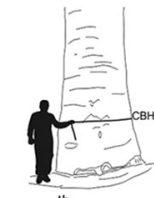

$8^{\text {th }}$ position

Araucária Gigante

Cruz Machado - PR $\mathrm{DBH}=2.13 \mathrm{~m}$ $\mathrm{CBH}=6.70 \mathrm{~m}$ Height $=40 \mathrm{~m}$ $53.5 \mathrm{~m}^{3}$

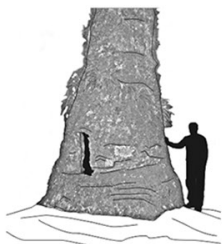

$4^{\text {th }}$ position

Menina da Cústodia São Joaquim - SC $\mathrm{DBH}=2.25 \mathrm{~m}$ $\mathrm{CBH}=7.07 \mathrm{~m}$ Height $=39.3 \mathrm{~m}$ $63.3 \mathrm{~m}^{3} / \mathrm{f}_{1,3}: 0.4037$

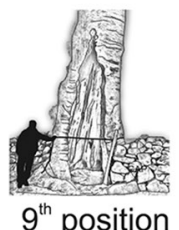

sition

Fazenda do Colégio São Joaquim - SC $\mathrm{DBH}=2.07 \mathrm{~m}$ $\mathrm{CBH}=6.53 \mathrm{~m}$ Height $=25.1 \mathrm{~m}$ $34.1 \mathrm{~m}^{3} / \mathrm{f}_{13}: 0.4002$

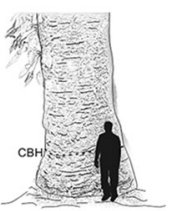

$11^{\text {th }}$ position Fazenda Santana Castro - PR $\mathrm{DBH}=2.01 \mathrm{~m}$ $\mathrm{CBH}=6.32 \mathrm{~m}$ Height $=\sim 44 \mathrm{~m}$ $61.0 \mathrm{~m}^{3} / \mathrm{f}_{13}: 0.4301$

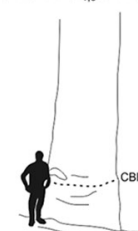

$17^{\text {th }}$ position Perra Indígena Mangueirin Serta Terinha - SC $\mathrm{DBH}=1.88 \mathrm{~m}$ Height $=38.7 \mathrm{~m}$ $33.5 \mathrm{~m}^{3} / \mathrm{f}_{13}: 0.4021$

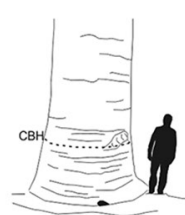

$12^{\text {th }}$ position

Santo Anjo 2 Alfredo Wagner - SC

$\mathrm{DBH}=2.01 \mathrm{~m}$

$\mathrm{CBH}=6.31 \mathrm{~m}$

Height $=>35 \mathrm{~m}$

$43.9 \mathrm{~m}^{3}$

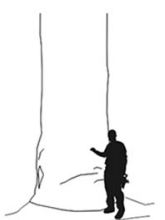

$18^{\text {th }}$ position

Chopinzinho $-\mathrm{PR}$

$\mathrm{CBH}=5.88 \mathrm{~m}$

Height $=37 \mathrm{~m}$

$47.8 \mathrm{~m}^{3} / \mathrm{f}_{13}: 0.4172$

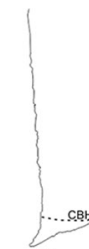

$13^{\text {th }}$ position Gateados Capão Alto - SC $\mathrm{DBH}=2.00 \mathrm{~m}$ $\mathrm{CBH}=6.28 \mathrm{~m}$ Height $=\sim 35.4 \mathrm{~m}$

$38.2 \mathrm{~m}^{3}$

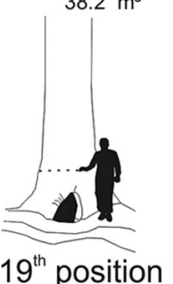

$19^{\text {th }}$ position

Alfredo Wagner - SC

$\mathrm{DBH}=1.84 \mathrm{~m}$

$\mathrm{CBH}=5.79 \mathrm{~m}$

Height $=>31 \mathrm{~m}$ $\sim 31.8 \mathrm{~m}^{3}$

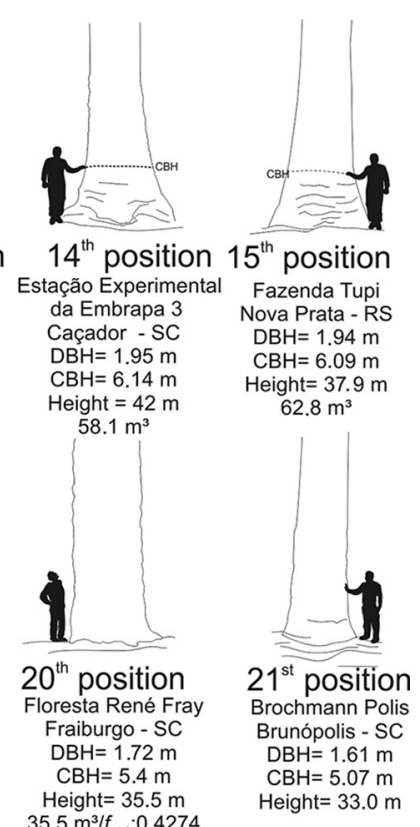

Figure 2 - Basal profiles of giant araucarias in southern Brazil, with their respective locations, dendrometric measurements, and artificial factor $\left(f_{1,3}\right)$, categorized by diameter size in descending order. 
thickness of the bark was analysed at the edges of the basal cavities. The height of the cavity at the central axis was measured using the vertical distance with a survey laser. Photographs of the trunk base were taken in order to create drawings to represent tree scale. The illustrations of the tree bases included a profile of a person 1.8 $\mathrm{m}$ tall to show the scale. The images were formulated in Photoshop $^{\mathrm{TM}}$ and then drawn using the CorelDraw $\mathrm{X}^{\mathrm{TM}}$ software program (Van Pelt, 2001).

\section{Results and Discussion}

\section{Giant Araucarias}

We found 21 trees with $\mathrm{DBH}$ larger than $1.60 \mathrm{~m}$. The largest existing $A$. angustifolia is called 'Pinheirão' (large pine) and has large basal cavities that allow a person to pass through in an upright position (Figure 2). The cavities made this tree undesirable to loggers who exploited the same area located in São Joaquim in four annual cutting cycles until the early 1980s according tho the owner's records. However, the scarcity of wood in the modern marketplace has made such trees attractive because the volume of wood in higher positions on the trunk would be sufficient to make harvesting economically viable. If not for the current owner and his ancestors refusing to sell this tree to sawmills, it would most likely have been harvested. This is a monumental tree, the only living proof of the potential growth and longevity in the species. It is the only tree of the species that exceeds $3 \mathrm{~m}$ in diameter and $100 \mathrm{~m}^{3}$ in volume. Access to the tree requires authorization from the owners, who use the tree to generate ecological tourism revenue.

The second largest araucaria is known as 'Pinheiro Grosso' (thick pine) and is located in the Pinheiro Grosso Municipal Park. It is the only tree among the giant araucarias located at a site with a complete tourist infrastructure. This tree is visited by more than 13,000 people per year, according to park registrations between 2012 to 2015. Other smaller araucaria trees located in isolated sites without adequate infrastructure are less well known and do not promote ecotourism.

The third largest araucaria tree is located in the municipality of Caçador (state of SC) and belongs to an Experimental Station (Brazilian Agriculture Research Corporation). Visitation to this tree is restricted. The site is a forest fragment with a history of intense human exploitation that contains two giant trees, both of which are listed in this study. This close proximity between these two trees prompts us to speculate that in the past these large trees were more common and could be found with high frequency. We observed a similar situation in the municipality of Alfredo Wagner where in the locale of Santo Anjo three large trees were listed, one of which measured $1.84 \mathrm{~m}$ DBH. Reitz (1966) reports similar in the municipality of São Joaquim. The three largest araucarias in Brazil surpass in size the largest Chilean araucaria (Araucaria araucana) which has a diameter of $2.3 \mathrm{~m}$ (Gutiérrez, 2016). The same author observed that monu- mental tree heritages were not recognized in Chile. We also detected this lack of recognition of araucarias as monumental trees in Brazil.

The volumes of these araucaria trees are very substantial, ranging from $38.2 \mathrm{~m}^{3}$ to $106.6 \mathrm{~m}^{3}$. The artificial form factor $\left(f_{1,3}=\right.$ the proportion of the real volume with bark divided by the cylindrical volume obtained by basal area at the position of $1.3 \mathrm{~m}$ above ground level in height multiplied by the height of the tree) calculated for these large trees was in average 0.3745 , ranging between 0.3279-0.4585 (Figure 2). In the case of the large trees, the basal structures including reaction wood and prop roots cause a greater thickening of the basal diameter and increase the cylindrical volume. Thus, it justifies the smaller value of the form factor that is opposite to that used for young trees $(0.54-0.69)$ with right-angled trunk bases (Sanquetta et al., 2014). This parameter can also be useful in defining giant trees, adding to the others proposed by Lindenmayer and Laurence (2016).

Araucaria angustifolia is under critical threat of extinction (Thomas, 2013) due to a drastic reduction in population size caused by deforestation and logging. These disturbances have altered the diametric structure (Souza, 2007; Souza et al., 2012; Vibrans et al., 2013) and reduced the number of large individuals of this species in the Araucaria Forest. Our results reflect a situation typical for giant araucaria trees across Brazil; nearly all the giant trees are gone from forests with only a few recent records found (Backes and Nilson, 1983; Reitz, 1966). Recent bibliographies (Albiero Jr. et al., 2015; Carvalho, 2003; Oliveira et al., 2009) include diametric information inferior to that identified in this study; in addition, the inventory data of the states of Rio Grande do Sul and Santa Catarina do not include araucaria trees larger than $1.5 \mathrm{~m}$ in diameter. Logging of $A$. angustifolia affected old and large trees. To date, we have identified only 13 trees having at least $2 \mathrm{~m}$ in diameter at breast height (DBH).

Although we do not analyze tree ages, other factors such as relative size, diameter, and height should be considered in a species-specific way when estimating the ecological importance of a monumental tree (Lindenmayer and Laurance, 2016). A valuable survey technique would be to define the typical minimum diameter of reproductively mature individuals and a small percentage of all reproductive trees. However, the largest individuals of any particular tree species may not always be the oldest because fast-growing species can reach large sizes relatively quickly (e.g.: Eucalyptus regnans F. Muell.). In addition, the oldest living trees are not always the tallest trees as older trees exposed to environmental factors can lose canopy biomass and, thus, height (example.g.: Pinus longaeva D.K. Bailey). Other important features that reflect tree age are a reinforced basal trunk (buttressing) with thick bark and the presence of large and numerous cavities (Lindenmayer and Laurance, 2016). We examined these characteristics in the giant araucaria trees sampled in our study. The thickness of the bark 
in basal cavities ranged between $15 \mathrm{~cm}$ to $22 \mathrm{~cm}$. Thus, this species is also able to survive forest fires, which allows them to reach large dimensions and achieve greater longevity.

\section{Cavities}

The presence of cavities was seen in all the giant trees in our study although the size and quantity varied (Figure 2). The trees located in Campos Novos, Capão Alto and Nova Petrópolis are the only individuals without large cavities exposed at the base of the trunk. In the large basal cavities, we verified the presence of bats, highlighting the importance of these large, old trees for wildlife habitat (Lindenmayer and Laurance, 2016). The 'Pinheirão', 'Estação Experimental Embrapa 1', and 'Fazenda do Colégio' trees had the largest cavities with openings between 1 to $2 \mathrm{~m}$ wide and heights of up to 4.4 $\mathrm{m}$. The internal areas of these cavities ranged from $3 \mathrm{~m}^{2}$ to $6 \mathrm{~m}^{2}$; therefore, they are true vertical biological caves. The ceiling height in 'Pinheirão' measured 14 meters along the central main trunk axis.

Small basal cavities less than $50 \mathrm{~cm}$ in height and width are common in most large araucarias. These small cavities provide important access to the large inner chambers of the tree and are important places of refuge for mammals such as the coatis (Nausa nasua) and the wild pigs (Tayassu pecari) (Beisiegel, 2006). Cavities measuring more than $2.5 \mathrm{~m}$ in height are considered excellent nesting sites for birds and shelters for bats (Bernard, 2001; Cockle et al., 2010). We found large cavities high up in the trunk; for example, the 'Pinheiro Grosso' has a cavity at a height of 33 meters that is $1.90 \mathrm{~m}$ in height and $0.35 \mathrm{~m}$ wide. We also identified man-made cavities in the main trunk of these large trees. The 'Menina da Custódia' tree has a rectangular opening $(40 \times 80 \mathrm{~cm})$ at the base of the tree (Figure 2), as well as scars of transverse cuts $(67 \times 33 \mathrm{~cm})$ that were not completely surrounded by the bark. The 'Santo Anjo 2' tree also has these artificial scars created by timber valuation methods. The trees in this locale, according to the owner, were sold to a sawmill in the year 2000, but the araucarias were not cut due to protection by law of endangered Atlantic Forest flora species (MMA, 2001). Despite the presence of cavities and non-commercial basal wood, it is possible that these trees would have been harvested had it not been for the protection by law being in place.

\section{Size distribution}

In the state inventories of Rio Grande do Sul (RS) and Santa Catarina (SC), 1,810 and 1,697 araucaria trees were measured, respectively. The largest araucaria trees in DBH showed $144 \mathrm{~cm}$ in RS and $108 \mathrm{~cm}$ in SC, both being $27 \mathrm{~m}$ in height (Figure 3). Data presented in Figure 3 reinforce the notions that i) the araucarias measured in this study are much bigger than those found in other inventories across the states of SC and RS; and ii) the rarity of the individuals sampled in the present study thus provides a robust argument for the 'giant'

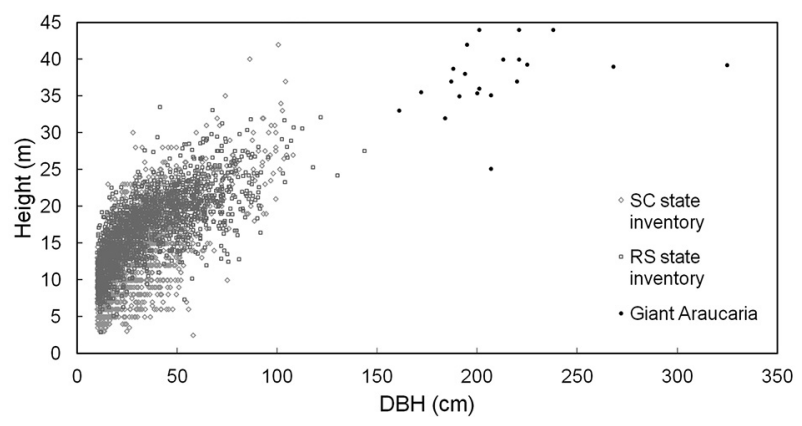

Figure 3 - Araucaria diameter at breast height (DBH) and height relationship showing size distribution of the giant araucarias $(n=$ 21 ) in relation to the individuals sampled in the state inventories of Santa Catarina (SC) and Rio Grande do Sul (RS) ( $n=3,529$ ). The largest individuals observed in the state surveys are highlighted in black.

nomenclature (araucaria trees $\geq 1.5 \mathrm{~m}$ in DBH and $\geq 30$ $\mathrm{m}$ in height). Much of the research on old-growth forests in North America has focused on stands dominated by Douglas-fir (Pseudotsuga menziesii) and other giant trees. These studies acknowledge that the single most important element of old-growth canopy structure is the giant tree (Van Pelt, 2001; Van Pelt and Sillett, 2008). Thus, a relatively high density of large trees is characteristic of a mature forest (Souza et al., 2012), and the absence of araucaria individuals with DBH larger than $150 \mathrm{~cm}$ in both state inventories demonstrates the diametric distribution imbalance of forest remnants in southern Brazil. This is a consequence of fragmentation, chronic disturbance, logging and degradation in the Araucaria forest (Souza et al., 2012). We found giant trees located in only old forests with very low historical anthropic action in Gateados, Santo Anjo and Fraiburgo. As to fragmentation, Laurance et al. (2000) pointed out the close relationship between forest fragmentation and survival of big trees in Amazonian forests, citing higher exposure of tree crowns to wind turbulences, lianas, radiation and evaporation near forest edges as reasons for breakage and mortality of big trees. Another aspect is the forest management practiced in the Brazilian Amazon forest without protection of the big trees. The maintenance of large trees in areas of natural forest management should be examined with a view to maintaining not only large trees with cavities as "mother trees or seed-trees" (to support young trees or seedlings). This practice leads to genetic loss and lack of information about the growth potential of tree species with phenotypic quality for silvicultural use and future new monumental trees.

There was no legal protection for araucaria trees before 2001, a permissive situation that encouraged their devastation across large areas. Less than two decades was sufficient to demonstrate the efficacy of an apparatus for protecting araucaria trees, and revealed the high potential for regeneration of the species. Travelling across southern Brazil, forest fragments dominated 
by $A$. angustifolia are abundant because the species is a long-lived pioneer, though not resilient to the disturbance represented by logging (Souza, 2007; Souza et al., 2008; Souza et al., 2012). Thus, forest researchers and other stakeholders should be encouraged to embrace the sustained management of these fragments and the recruitment of new trees to the giant class. It is also necessary to know whether there is potential growth in the species for the development of natural forest ecosystem management and stand structure of araucaria old forests as carried out in areas of old-growth forests in California, Oregon and Washington (Franklin et al., 2002; Van Pelt, 2001; Van Pelt and Sillett, 2008). Thus, giant araucaria trees are more valuable standing as monumentals in forest areas. The example of 'Pinheiro Grosso', visited by more than 13,000 people per year, shows that society is interested in these trees and is demanding this kind of touristic and cultural activity.

\section{Conclusions}

Four conclusions can be highlighted: 1) giant araucarias with $>2.00 \mathrm{~m}$ in diameter are rare and only 13 individuals could be found in southern Brazil; 2) araucaria trees with $1.5 \mathrm{~m}$ in $\mathrm{DBH}$ are a robust argument for the giant class nomenclature and to be treated as momumental trees; 3) a priority action of governments is to recognize and preserve the monumental trees and their genetic resources; 4) a need for a public policy of specific forest inventories of large trees.

\section{Acknowledgments}

The authors are grateful to Embrapa Florestas for permission to access the Estação Experimental area in Caçador and to Fundação de Amparo à Pesquisa e Inovação do Estado de Santa Catarina (FAPESC) for supporting the Inventário Florístico Florestal de Santa Catarina (IFFSC). We also wish to thank rural landowners, the managers of the Pinheiro Grosso Park, those who indicated the locations of trees and contributed to the survey, the post-graduate program for Forestry Engineering at Universidade Federal de Santa Maria (UFSM) for their support with dendrometry equipment, and the $\mathrm{CNPq}$ - Conselho Nacional de Desenvolvimento Científico e Tecnológico for the post-doctoral scholarship aid received by the first author (Proc.158252/2015-2); Alexander Christian Vibrans has also been constantly funded by CNPq (grant \#312075/2013-8).

\section{Authors' Contributions}

Conceptualization: Scipioni, M.C. Data acquisition: Scipioni, M.C., Longhi, S.J., Vibrans, A.C. Data analysis: Scipioni, M.C., Dobner Jr, M. Design of methodology: Scipioni, M.C. Writing and editing: Scipioni, M.C., Dobner Jr, M., Longhi, S.J., Vibrans, A.C., Schneider, P.R.

\section{References}

Albiero Jr., A.; Temponi, L.G.; Galvão, F.; Botosso, P.C.; Tereza, A.; Guimarães, B. 2015. Population structure of Araucaria angustifolia in the Iguaçu National Park. Floresta 45: 361-372.

Backes, A.; Nilson, A.D. 1983. Araucaria angustifolia (Bert.) O. Kuntze, Brazilian pine. Iheringia Série Botânica 30: 85-96 (in Portuguese, with abstract in English).

Beisiegel, B.D.M. 2006. Shelter availability and use by mammals and birds in an Atlantic forest area. Biota Neotropica 6: 1-16.

Bernard, E. 2001. Vertical stratification of bat communities in primary forests of central Amazon, Brazil. Journal of Tropical Ecology 17: 115-126.

Chassot, T.; Fleig, F.D.; Finger, C.A.G.; Longhi, S.J. 2011. Individual tree diameter growth model for Araucaria angustifolia (Bertol.) Kuntze in mixed ombrophylous forest. Ciência Florestal 21: 303-314 (in Portuguese, with abstract in English).

Cockle, K.L.; Martin, K.; Drever, M.C. 2010. Supply of treeholes limits nest density of cavity-nesting birds in primary and logged subtropical Atlantic forest. Biological Conservation 143: 2851-2857.

Eckenwalder, J.E. 2009. Conifers of the World. Tree Press, Portalnd, OR, USA.

Farjon, A.; Filer, D. 2013. An Atlas of the World's Conifers: An Analysis of their Distribution, Biogeography, Diversity and Conservation Status. Brill, Leiden, The Netherlands.

Franklin, J F.; Lindenmayer, D.B.; Thornburgh, D.A.; Pelt, R.; Van, Chen, J.; Spies, T.A.; Carey, A.B.; Shaw, D.C.; Berg, D.R.; Harmon, M.E.; Keeton, W.S.; Bible, K. 2002. Disturbances and structural development of natural forest ecosystems with silvicultural implications, using Douglas-fir forests as an example. Forest Ecology and Management 155: 399-423.

Gutiérrez, Â.G. 2016. Monumental trees: a natural patrimony not yet recognized in Chile. Bosque 37: 445-449 (in Spanish, with abstract in English).

Laurance, W.F.; Delamônica, P.; Laurance, S.G.; Vasconcelos, H.L.; Lovejoy, T.E. 2000. Rainforest fragmentation kills big trees. Nature 404: 836.

Lindenmayer, D.B.; Laurance, W.F. 2016. The ecology, distribution, conservation and management of large old trees. Biological Reviews DOI: 10.1111/brv.12290.

Lindenmayer, D.B.; Laurance, W.F.; Franklin, J.F. 2012. Global decline in large old trees. Science 338: 1305-1306.

Mattos, J.R. 2011. The Brazilian Pine Tree = O Pinheiro Brasileiro. ed. UFSC, Florianópolis, SC, Brazil (in Portuguese).

Mattos, P.P.; Santos, A.T.; Rivera, H.; Oliveira, Y.M.M.; Rosot, M.A.D.; Garrastazu, M.C. 2007. Growth of Araucaria angustifolia in the Embrapa/Epagri forest reserve, Caçador, SC, Brazil. Pesquisa Florestal Brasileira 55: 107-114 (in Portuguese, with abstract in English).

Ministério do Meio Ambiente [MMA]. 2001. Conama Resolution $\mathrm{n}^{\mathrm{o}} 278$, de 24 de maio de 2001. Provides for the cutting and exploitation of species threatened with extinction of the flora of the Atlantic Forest $=$ Resolução Conama $n^{\circ} 278$, de 24 de maio de 2001. Dispõe sobre o corte e a exploração de espécies ameaçadas de extinção da flora da Mata Atlântica. MMAConama, Brasília, DF, Brazil (in Portuguese). 
Narvaes, I.S.; Brena, D.A.; Longhi, S.J. 2005. Struture of natural regeneration in mixed rainy forest at São Francisco de Paula National Forest, RS. Ciência Florestal 15: 331-342 (in Portuguese, with abstract in English).

Oliveira, J.M.; Santarosa, E.; Pillar, V.D.; Roig, F.A. 2009. Seasonal cambium activity in the subtropical rain forest tree Araucaria angustifolia. Trees - Structure and Function 23: 107-115.

Reitz, R.K.R.M. 1966. Illustrated Catarinense Flora: Araucariaceas = Flora Ilustrada Catarinense: Araucariaceae. Herbário Barbosa Rodriguez, Itajaí, SC, Brazil (in Portuguese).

Sanquetta, C.R.; Corte, A.P.D.; Mognon, F.; Maas, G.C.B.; Lourenço Rodrigues, A. 2014. Individual carbon estimation for Araucaria angustifolia. Pesquisa Agropecuária Tropical 44: 1-8 (in Portuguese, with abstract in English).

Scheeren, L.W.; Gehrardt, E.J.; Finger, C.A.G.; Longhi, S.J.; Schneider, P.R. 2000. Grouping of sample units of Araucaria angustifolia (Bert.) O. Ktze. according to variables of the soil, of burlap and leafs, in the area of Canela, RS. Ciência Florestal 10: 39-57 (in Portuguese, with abstract in English).

Sillett, S.C. 1999. Tree crown structure and vascular epiphyte distribution in sequoia sempervirens Rain Forest Canopies. Selbyana 20: 76-97.

Sillett, S.C.; Van Pelt, R. 2000. A redwood tree whose crown is a forest canopy. Northwest Science 74: 34-43.

Sillett, S.C.; Van Pelt, R.; Kramer, R.D.; Carroll, A.L.; Koch, G.W. 2015. Biomass and growth potential of Eucalyptus regnans up to $100 \mathrm{~m}$ tall. Forest Ecology and Management 348: 78-91.

Souza, A.F. 2007. Ecological interpretation of multiple population size structures in trees: the case of Araucaria angustifolia in South America. Austral Ecology 32: 524-533.

Souza, A.F.; Cortez, L.S.R.; Longhi, S.J. 2012. Native forest management in subtropical South America: long-term effects of logging and multiple-use on forest structure and diversity. Biodiversity and Conservation 21: 1953-1969.

Souza, A.F.; Forgiarini, C.; Longhi, S.J.; Brena, D.A. 2008. Regeneration patterns of a long-lived dominant conifer and the effects of logging in southern South America. Acta Oecologica 34: 221-232.
Stefenon, V.M.; Steiner, N.; Guerra, M.P.; Nodari, R.O. 2009. Integrating approaches towards the conservation of forest genetic resources: a case study of Araucaria angustifolia. Biodiversity and Conservation 18: 2433-2448.

Stepka, T.F.; Figueiredo Filho, A.; Mattos, P.P.; Machado, S.A. 2014. Age and dendrochronology in native Araucaria, cedar and imbuia trees in southern Brazil = Idade e dendrocronologia em árvores nativas de araucária, cedro e imbuia no sul do Brasil. p. 117-164. In: Sanquetta, C.R.; Corte, A.P.D.; Rodrigues, A.L.; Mognon, F., eds. Forest with Araucaria: ecological research of long duration $=$ Floresta com Araucária: pesquisa ecológicas de longa duração. Peld, Curitiba, PR, Brazil (in Portuguese).

Thomas, P. 2013. IUCN Red List Threat. Species. Araucaria angustifolia. Available at: http://dx.doi.org/10.2305/IUCN. UK.2013-1.RLTS.T32975A2829141.en [Accessed Sept 30, 2016]

Tng, D.Y.P.; Williamson, G.J.; Jordan, G.J.; Bowman, D.M.J.S. 2012. Giant eucalypts - globally unique fire-adapted rain-forest trees? New Phytologist 196: 1001-1014.

Van Pelt, R. 2001. Forest giants of the Pacific coast. University of Washington Press, Seattle, WA, USA.

Van Pelt, R.; Sillett, S.C. 2008. Crown development of coastal Pseudotsuga menziesii, including a conceptual model for tall conifers. Ecological Monographs 78: 283-311.

Vibrans, A.C.; Sevegnani, L.; Gasper, A.L.; Lingner, D.V. 2013. Diametric structure of remnants of the mixed ombrophylous forest in Santa Catarina $=$ Estrutura diamétrica dos remanescentes da floresta ombrófila mista em Santa Catarina. p. 225-242. In: Vibrans, A.C.; Sevegnani, L.; Gasper, A.L.; Lingner, D.V., eds. Floristic forest inventory of Santa Catarina: Araucaria Forest = Inventário florístico florestal de Santa Catarina: floresta ombrófila mista. Edifurb, Blumenau, SC, Brazil (in Portuguese). 